\title{
Valorization of Filleting Waste of Epinephelus chlorostigma from Fish Freezing Industry for the Development of Value Added Edible Product
}

\author{
A. Manjunatha Reddy ${ }^{*}$, K. Elavarasan, M.H. Bhandary and R.M. Prabhu
}

Department of Fish Processing Technology, Karnataka Veterinary, Animal and Fisheries

Sciences University, Bidar, College of Fisheries, Mangalore, Karnataka-575001, India

*Corresponding author

\section{A B S T R A C T}

\begin{tabular}{|l|}
\hline Keyw or d s \\
Epinephelus \\
chlorostigma, \\
Reef cod, Cutlet \\
blend, Frozen \\
storage, Quality \\
changes, Fish \\
cutlet.
\end{tabular}

In the present investigation, we studied the biochemical changes in frozen stored cutlet blend $(\mathrm{CB})$ prepared using meat recovered from filleting frame waste of Epinephelus chlorostigma. In addition, we prepared fried cutlet from the $\mathrm{CB}$ during the frozen storage and evaluated organoleptically. Total volatile base nitrogen (TVB-N), tri-methyl amine nitrogen (TMA-N), peroxide value (PV), free fatty acids (FFA) and Thiobarbituric acid value $(\mathrm{TBA})$ of cutlet blend increased significantly $(\mathrm{P}<0.05)$ during 120 days of frozen storage. The increase in biochemical parameters were within the prescribed limit for fish and fishery products intended for human consumption. Sensory attributes of fried cutlet such as appearance, color, taste, texture and flavor decreased gradually with increase in storage days. At the end of storage study, the overall acceptability score was 7.76 indicate that the fried cutlets were liked moderately to very much. Present study has demonstrated the effective utilization and suitability of meat recovered from filleting frame waste of Epinephelus chlorostigma for the preparation of value added products like fish cutlet. It can also be inferred from the results that Cutlet blend, an intermediate or ready to prepare products could be stored at frozen condition for 4 months with minimum but acceptable loss in eating quality.

\section{Introduction}

Fish and fishery products are rich in protein. With the growing world population and increase in awareness on health benefits of fish consumption, there is an ever increasing demand for high quality fish protein diets and this could also be met through maximum utilization of fishery resources. In practice, fish is preserved by different methods like freezing, canning, salting etc. The preparation steps like dressing and filleting for almost all the processing methods are inevitable and remains same. Particularly, larger fishes are filleted, frozen and cold stored till they are sold out in domestic or international market. As a result of filleting, about $50 \%$ of the weight of the total raw material weight is lost in the form of waste and usually discarded. The filleting waste includes fish frame along with head and internal organs containing a bulk amount of meat (attached with frames and head) which may be made edible by recovering (Kim et al., 1996).

The fish meat (15-17\%) recovered from filleting frame waste is considered as a valuable and nutritionally rich raw material for the development of value added product. 
The species, Epinephelus chlorostigma, commonly known as reef cod forms a bulk of the grouper fishery along south west coast of India. CMFRI (Central Marine Fisheries Research Institute) has estimated the grouper landings of about 32,144 tones in India (CMFRI, 2014). The larger sized fish is generally filleted, frozen and exported. During this operation a considerable amount of waste is generated.

The developments in convenience products (ready to cook/ready to prepare/ready to eat), made from fish, is happening at faster rate for the following reasons: the improved customer acceptance for value added ready to eat (cooked/processed) fishery products like fish balls, burgers, nuggets and cutlets; and increased socio economic conditions of people due to urbanization; increased women work force and a move towards busy life style (Sowmya Praneeth et al., 2015). Studies on the biochemical changes of cutlet blend during frozen storage particularly from fish frame waste and its effect on organoleptic characteristics of final product that is fried cutlet are scanty.

Hence in the present research work, we focused on changes in biochemical quality of cutlet blend from filleting waste of Epinephelus chlorostigma during frozen storage and its effect on sensory quality of fried cutlet. The study is a timely need as the waste utilization of fishery by products is being researched extensively in the recent years.

\section{Materials and Methods}

\section{Raw material}

The raw material, fish filleting wastes from reef cod (Epinephelus chlorostigma), were supplied by local fish processing factory, Indo fisheries, Mangalore, Karnataka, India in chilled condition using crushed ice at the ratio of 1:1 (fish : Ice w/w). Filleting waste was stored at $<5{ }^{\circ} \mathrm{C}$ in the laboratory and utilized within $24 \mathrm{~h}$.

\section{Sample preparation (Cutlet blend and fried cutlet)}

Meat separation from filleting waste was carried out manually and cutlet blend (CB) was prepared according to Reddy and Bhandary (2015). Samples of CB was packed in quantities of $250 \mathrm{~g}$ in low-density polyethylene bags $(3 \times 4)$, sealed and frozen in the air blast freezer (Armfield, Armfield Limited, Ringwood Hampshire, England) at $35^{\circ} \mathrm{C}$ and all the packs were stored in the deep freezer (Vest frost, Holland) at $-20^{\circ} \mathrm{C}$ for a period of 120 days.

Samples from 3 independent packs were drawn $(250 \mathrm{~g})$ on monthly intervals and thawed at refrigerated temperature. Thawed cutlet blend was molded into circular shape using a mold, coated with bread crumbs and shallow fried in double refined sunflower oil using a non-stick pan. The average weight of fried cutlet was $32 \mathrm{~g}$.

\section{Analysis}

\section{Proximate composition}

Proximate composition of cutlet blend (CB) includes moisture, crude protein and ash were estimated according to the methods given in A.O.A.C. (2000) and total lipid was determined according to the method described by Bligh and Dyer (1959) using chloroform and methanol mixture as a solvent for lipid extraction.

\section{Biochemical quality indices}

\section{Total volatile base nitrogenous compounds}

Total volatile base nitrogen (TVB-N) and Trimethylamine nitrogen (TMA-N) were 
estimated by the method of Beatty and Gibbons (1937).

\section{Lipid quality indices}

Peroxide value (PV) and free fatty acid (FFA) contents were determined according to the method of Jacobs (1958) and Takagi et al., (1984) respectively using chloroformmethanol extract of lipids prepared from cutlet blend (CB).

Thiobarbutric acid reactive substance (TBARS) value was determined as per the method given by Tarladgis et al., (1984) and expressed as $\mathrm{mg}$ malanoldehyde $/ \mathrm{kg}$ of lipid.

\section{Sensory analysis}

The fried cutlets prepared were served warm for a group of trained panelists $(n=10)$ for sensory evaluation and asked to score based on a 9 point hedonic scale.

The attributes included were appearance, colour, taste, texture, flavor and overall acceptability. The descriptions given for the allotment of score are as follows: Like extremely-9; Like very much-8; Like moderately-7; Like slightly-6; neither like nor dislike-5; Dislike slightly-4; Dislike moderately-3; Dislike very much-2; Dislike extremely-1.

\section{Statistical analysis}

All the analyses were carried out in triplicate. The homogeneity of variance was analyzed using one way ANOVA. To test the significant difference, Duncan's multiple range mean comparison test was performed.

Correlation coefficient between the variables was analyzed using Pearson correlation coefficient and the significance of correlation was tested using student's ' $t$ ' test. All the statistical analyses were performed using statistical programme SPSS 16 (SPSS.16.0 for windows, SPSS Inc., Chicago, IL,).

\section{Results and Discussion}

\section{Changes in proximate composition}

During the present course of investigation, we evaluated the changes in proximate composition which includes moisture, protein, fat and ash of cutlet blend (CB) (Table 1). Moisture and protein of $\mathrm{CB}$ decreased significantly from $73.66 \%$ to $71.28 \%$ and $15.78 \%$ to $14.06 \%$ respectively. According to Umesh Bhatta et al.,(2015) the slight loss in moisture content may be attributed to structural damage to cell caused by the ice crystals formed during freezing and subsequent dehydration during frozen storage. Rathod and Pagarkar (2013) reported the loss of moisture due to denaturation of proteins during freezing and frozen storage and the loss of protein because of leaching effect of water soluble proteins with drip. Total fat content of CB didn't differ significantly during storage between 0 day and $120^{\text {th }}$ day (3.6\% to $4.19 \%)$. The increase in total fat and ash might be due to decrease in moisture Pawar et al., (2013). Reddy and Bhandary (2015) reported similar findings for frozen stored fried fish cutlet prepared from filleting waste of reef cod for a period of 4 months. Pawar et al., (2013) reported the similar effect on proximate composition of fried and frozen stored fish cutlet prepared from Catla catla meat.

\section{Changes in TVB-N and TMA-N contents}

Evaluation of quality of fish and fishery products are carried out by measuring the total volatile base nitrogenous (TVB-N) compounds and tri-methyl amino nitrogen Serdaroglu and Deniz (2001). Changes in TVB-N of frozen stored CB are given in figure 1 . There was a significant $(\mathrm{P}<0.05)$ and linear increase $(r=0.976)$ in TVB-N content 
from 8.69 to $14.08 \mathrm{mg}-\mathrm{N} / 100 \mathrm{~g}$ of $\mathrm{CB}$ during 120 days of frozen storage. Connell (1995) has suggested that TVB-N value of 40-50 mg$\mathrm{N} / 100 \mathrm{~g}$ of fish meat as the acceptable range. The nucleotide breakdown products, deamination of amino acids by microbial action and degradation of TMAO results in the formation of $\mathrm{NH}_{3}$, TMA and DMA which further on accumulation leads to increase in TVB-N content during frozen storage of fish meat. According to Contreras-guzman (2002) the rate of quality deterioration depends on the nature of pre-processing operations and frozen storage condition. Changes in TMA-N of frozen stored cutlet blend are given in figure 2. TMA-N content of cutlet blend increased significantly from 2.88 to $4.64 \mathrm{mg}$ $\mathrm{N} / 100 \mathrm{~g}$ of cutlet blend ( 0 day to $120^{\text {th }}$ day). There was no significant difference in $\mathrm{CB}$ from month 1 to 3 during frozen storage. Significant positive correlation between storage period and TMA-N $(r=0.857, \mathrm{P}<0.01)$ was observed. However, throughout the storage study the TMA-N was within the acceptable limit of 10-15 mg-N/100g (Huss, 1988) indicated the acceptability of cutlet blend.

\section{Changes in lipid quality}

Changes in lipid quality of frozen stored fish and fishery products are generally assessed by quantifying FFA, PV and TBARS. FFA, PV and TBARS of frozen stored cutlet blend are given in figure $2 \mathrm{~A}, \mathrm{~B}$ and $\mathrm{C}$. Lipid oxidation of food products leads to quality deterioration and further formation of toxic substances reported by Summo et al., (2006) and Murphy et al., (2004). The hydrolytic rancidity is indicated by FFA. Lipolytic enzymes also hydrolyze the triglycerides results in formation of FFA. Interactions of lipids and/or fatty acids with molecular oxygen produce free radicals which are highly reactive due to their unpaired electronic configuration. Thus propagate the oxidation reaction via the formation of peroxy-radicals (primary oxidation products). Subsequently, degradation of lipoperoxy radicals produce aldehydes and ketones (secondary oxidation products) (Gray et al., 1996; Devadasan, 2006). In the present investigation, a significant positive correlation was observed between the lipid quality parameters of cutlet blend such as FFA ( $\mathrm{r}=0.884, \mathrm{P}<0.01)$, PV $(\mathrm{r}=0.994, \mathrm{P}<0.01)$, TBARS $(\mathrm{r}=0.864, \mathrm{P}<0.01)$ and storage period. The FFA, PV and TBA of cutlet blend increased from 2.71 to $6.64 \%$ as oleic acid to the total lipids, 12.86 to 51.79 milliequivalent $\mathrm{O}_{2} / \mathrm{kg}$ of lipid and 0.574 to $0.707 \mathrm{mg}$ of malanoldehyde / $\mathrm{kg}$ of lipid, respectively from 0 to $120^{\text {th }}$ day and were found to be significant $(\mathrm{P}<0.05)$. Chowdhury et al., (2008) reported similar result in the study on frozen storage of fish cake prepared from silver carp mince. In most of the cases, there was an increase in lipid quality related parameters (FFA, PV and TBA) of fish mince and mince based products during frozen storage. In the present study, during frozen storage, the change in PV was more apparent than the changes in FFA and TBA. Frozen stored fish cutlet prepared from catla meat for a period of 150 days, showed increase in PV and FFA content (Pawar et al., 2013).

Table.1 Changes in the proximate composition of Cutlet blend during initial and end of frozen storage

\begin{tabular}{lcc}
\hline Proximate composition & $\mathbf{0}^{\text {th }}$ Day & $\mathbf{1 2 0}^{\text {th }}$ Day \\
\hline Moisture (\%) & $73.66 \pm 0.57$ & $71.28 \pm 0.44$ \\
Protein (\%) & $15.78 \pm 0.37$ & $14.06 \pm 0.30$ \\
Lipid (\%) & $3.6 \pm 0.45$ & $4.19 \pm 0.27$
\end{tabular}




\section{Mean \pm Standard deviation values from triplicates}

$2.53 \pm 0.24$

$3.50 \pm 0.30$

Fig.1 Changes in total volatile base nitrogen (TVB-N) and trimethyl amino nitrogen (TMA-N) of cutlet blend during frozen storage at $-20^{\circ} \mathrm{C}$ for 120 days. Different small alphabates on error bars indicate the significant difference $(\mathrm{p}<0.05)$

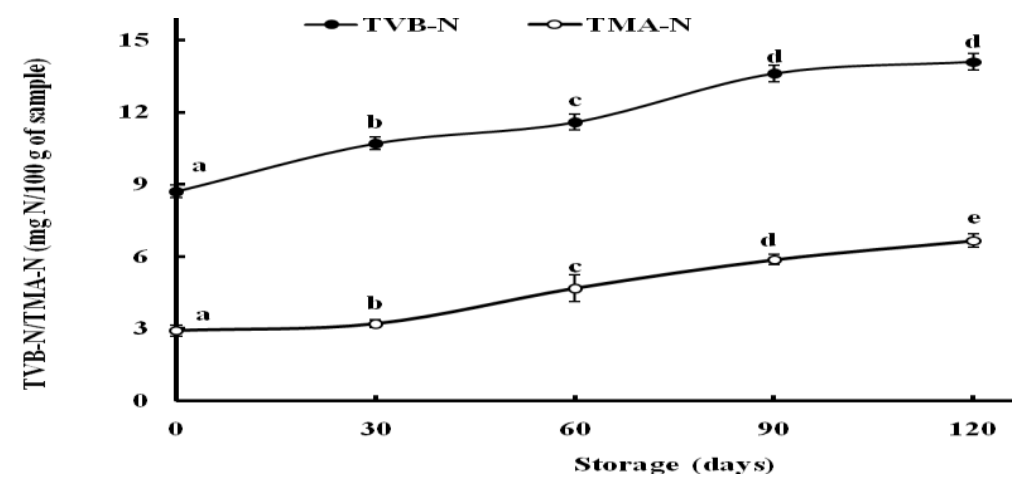

Fig.2 Changes in free fatty acids (FFA), peroxide value (PV) and thiobarbutiric acid reactive substances (TBARS) of cutlet blend during frozen storage at $-20^{\circ} \mathrm{C}$ for 120 days. Different small alphabates on error bars indicate the significant difference $(\mathrm{p}<0.05)$
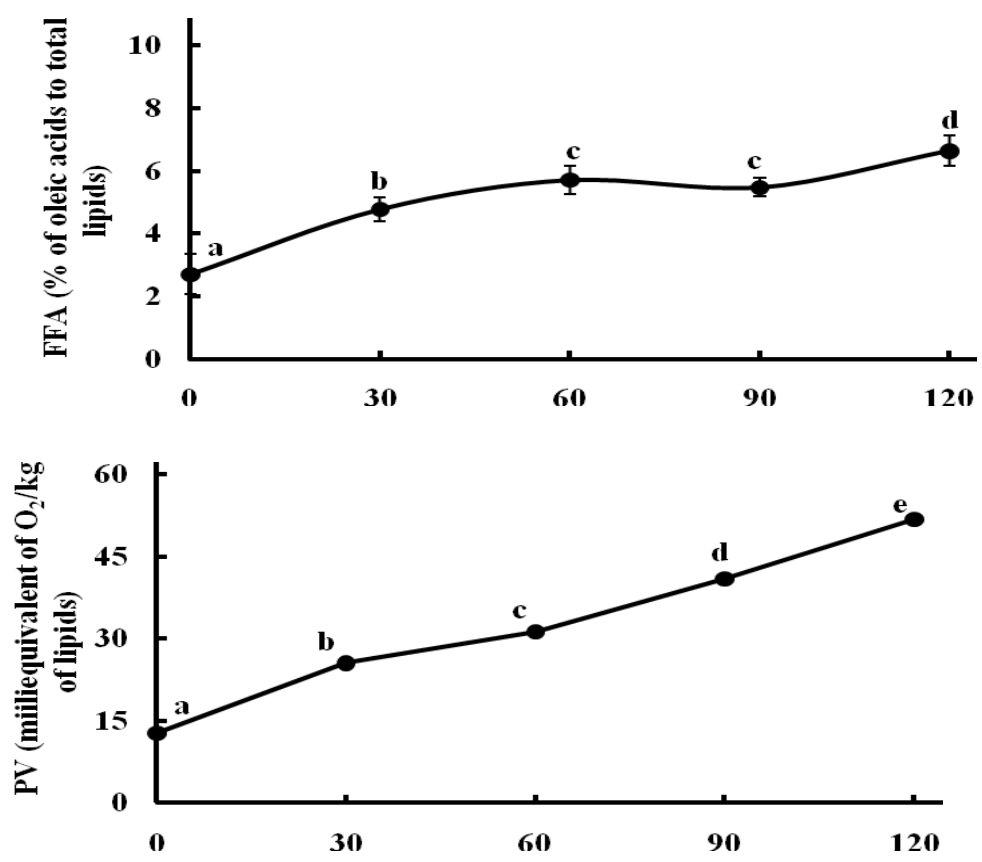


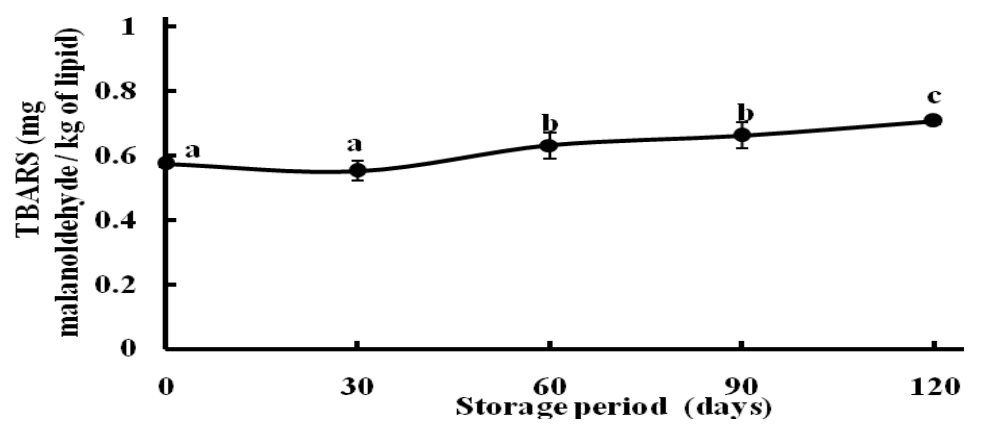

Fig.3 Changes in sensory attributes of fried cutlet prepared from cutlet blend during frozen storage at $-20^{\circ} \mathrm{C}$ for 120 days

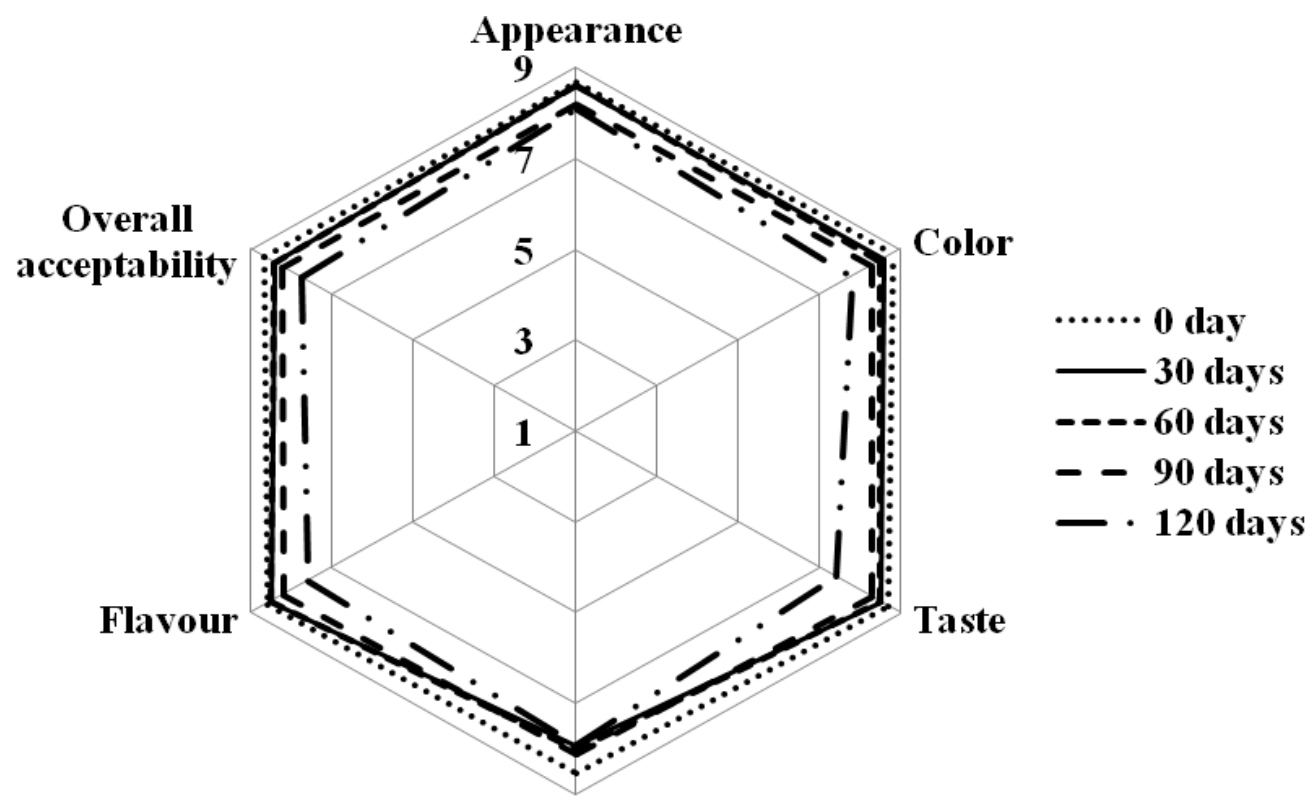

Texture

Similarly, frozen stored fish cutlet prepared from Wallago attu revealed increase in FFA and TBA content as reported by Undeland and Lingnert (1999). From the results, it is evidenced that though the cutlet blend stored at frozen condition, the lipid deterioration continues to certain extent. This may be retarded by the use of antioxidants and low temperature storage alone may not be sufficient particularly for complex food stuffs like fish cutlet blend.

\section{Changes in the sensory characteristics}

Cutlets prepared from frozen stored cutlet blend were subjected for sensory evaluation to a group of trained panelists $(\mathrm{n}=10)$ on 30 days interval for a period of 120 days of frozen storage and the results are depicted in figure 3 . There was no significant decrease in the sensory scores obtained for appearance and texture $(\mathrm{P}>0.05)$. However, the scores obtained for taste, flavor, color of the fried cutlet prepared from cutlet blend on $120^{\text {th }}$ day of frozen storage was significantly low $(\mathrm{P}<0.05)$. The correlation of storage days with sensory attributes such as appearance ( $\mathrm{r}=-$ 0.593 , $\mathrm{P}<0.005)$, color $(\mathrm{r}=-0.785, \mathrm{P}<0.01)$, 
taste $(\mathrm{r}=-0.653, \mathrm{P}<0.01)$, flavor $(\mathrm{r}=-0.634$, $\mathrm{P}<0.05)$ and overall acceptability $(\mathrm{r}=-0.699$, $\mathrm{P}<0.01)$ was found to be negative and significant $((\mathrm{P}<0.05)$. However, the low " $\mathrm{r}$ " value indicates that the correlation between the sensory attributes and storage days was weak. The weak correlation could be due to complexity of food system studied. The overall acceptability of the product with the biochemical parameters such as TMA-N, TVB-N, PV, FFA and TBARS was found to be negative. This means that the acceptability decrease with increase in biochemical quality indices.

However, statistically there was no significance in the correlation between PV, FFA, TBA of cutlet blend and overall acceptability of fried cutlet. Moreover, a significant correlation was found to be present for the TVBN and TMA-N of frozen cutlet blend with overall acceptability of fried cutlet. The overall acceptability of the cutlet at the end of the storage study was judged as good by the panelists. The decrease in sensory characteristics could be related to the formation of low molecular weight volatile compounds, oxidation of lipids, degradation and denaturation of proteins during freezing and frozen storage. These results were in accordance with Undeland, and Lingnert (1999).

\section{Acknowledgement}

Authors wish to thank the Dean, College of Fisheries, Mangaluru for his support and encouragement to carry out this study. The study was a part of M.F.Sc. research work carried out by the first author and submitted to KVAFSU, Bidar.

\section{References}

A.O.A.C., 2000. Official methods of analysis, $17^{\text {th }}$ ed. Association of Official Analytical Chemists, Washington D.C.
Beatty, S.A., and Gibbons, N.E. 1937. The measurement of spoilage in fishery. $J$. Biol Board Can., 3: 77-91.

Bligh, E.G., and Dyer, W.J. 1959. A rapid method of total lipid extraction and purification. Can.J. Biochem Physiol., 37: 911-917.

Chowdhury, S., Sarkar, S. and Dora, K.C. 2008. Quality changes in fish cakes prepared from washed Silver carp mince under frozen storage $\left(-20^{\circ} \mathrm{C}\right)$. Ind. J. Nutr. Dietet, 45:78-85.

CMFRI, 2014. Annual bulletin 2014-2015. Central Marine Fisheries Research Institute. Cochin, India. 20-21.

Connell, J.J. 1995. Control of Fish Quality, Fishing News Books, Farnham, Surrey, England, 152-157.

Contreras-guzmán, E.S. 2002. Biochemistry of Fish and Invertebrates. Cecta-Usach Press, Santiago, Chile (in Spanish).

Devadasan, K., 2006. Proteins and lipids of marine products and their changes during processing and preservation. In: Text book of fish processing technology. Gopakumar (Ed). ICAR New Delhi, pp. 122-158.

Gray, J.I., Gomaa, E.A. and Buclkey, D.J. 1996. Oxidative quality and shelf life of meats. Meat Sci., 43: 111-123.

Huss, H.H. 1988. Quality and Changes in fresh Fish. FAO Fisheries Series Technical Paper No 348.

Jacobs, M.B.1958. The chemical analysis of foods and food products, Krieger Publishing Co., Inc New York, 393394.

Kim, J.M., Liu, C.H., Eun, J.B., Park, J.W., Oshimi, R., Hayashi, K., Ott, K., Aramaki, T., Sekine, M., Horikita, Y., Fujimoto, K., Aikawa, T., Welch, L. and Long, R. 1996. Surimi from fillet frames of channel catfish. J. Food. Sci., 61: 428-431.

Manjunatha Reddy, A., Bhandary, M.H. 2015. Biochemical and sensory 
acceptability of cutlet prepared from filleting waste of reef cod. J. Food. Proc. Pre., 39: 369-375.

Murphy, S.C., Gilroy, D., Kerry, J.F., Buckley, D.J. and Kerry, J.P. 2004. Evaluation of surimi, fat and water content in a low/no added pork sausage formulation using response surface methodology. Meat Sci., 66: 689-701.

Pawar, P.P., Pagarkar, A.U., Rathood, N.B., Patil, S.S. and Mahakal, B.V.2013. Effect of frozen storage on biochemical and sensory quality changes of fish cutlets, made from freshwater fish catla (Catla catla). Int. J. Bioass., 2: 789-793.

Rathod, N. and Pagarkar, A. 2013. Biochemical and sensory quality changes of fish cutlets, made from pangasius fish (Pangasianodon hypophthalmus), during storage in refrigerated display unit at -15 to $-18^{\circ} \mathrm{C}$. Int. J. Food. Agri.Vete, Sci., 3: 1-8.

Serdaroglu, M. and Deniz, E.E. 2001. Balıklardavebazısuürünlerindetrimetila minvedimetilaminoluşumunuetkileyenfa ktörler. EU. Su. Ürünleri. Dergisi, 18: 575- 581 (in Turkish).

Sowmya Praneeth, S., Dhanapal, K., Reddy, GVS and Balasubramanian, A. 2015. Development of fish finger from rohu (labeo rohita) and its quality evaluation during refrigerated storage condition. Int. J. Sc., Envi. Tech., 4: 1457- 1468.

Summo, C., Caponio, F. and Pasqualone, A. 2006. Effect of vacuum packaging storage on the quality level of ripened sausages. Meat Sci., 74: 249-254.

Takagi, T., Hayashi, K. and Itabashi, Y.1984.Toxic effect of free unsaturated fatty acids in mouse assay of diarrlutic shellfish toxin by intra peritoneal injection. Bull. Jap. Soc. Sci Fish, 50: 1413-1418.

Tarladgis, B., Watts, B.M. and Yonathan, M. 1960. Distillation method for determination of malonaldehyde in rancid food. J. Amer. Oil.Che. Soci, 37: 44-48.

Umesha Bhatta, B., Prabhu, R.M, Manjunatha Reddy, A. and Elavarasan, K. 2015. Biochemical Changes in Dressed Priacanthus hamrur (Bull's Eye) During Frozen Storage and Its Effect on Physical and Sensory Quality of Fish Sausage. Int. J. Food. Prop., 18: 897-908.

Undeland, I., and Lingnert, H. 1999. Lipid oxidation in fillets of herring (Clupea harengus) during frozen storage. Influence of prefreezing storage. J. Agric. Food. Chem., 47: 524-532.

\section{How to cite this article:}

Manjunatha Reddy, A., K. Elavarasan, M.H. Bhandary and Prabhu, R.M. 2017. Valorization of Filleting Waste of Epinephelus chlorostigma from Fish Freezing Industry for the Development of Value Added Edible Product. Int.J.Curr.Microbiol.App.Sci. 6(8): 2879-2886.

doi: https://doi.org/10.20546/ijcmas.2017.608.344 